\title{
SELECTED LEgAL REgULATIONS REGARDING THE FIGHT AGAINST CORRUPTION
}

\section{WYBRANE UREGULOWANIA PRAWNE DOTYCZĄCE ZWALCZANIA KORUPCJI}

\begin{abstract}
One of the basic elements that guarantees effective anti-corruption is effective law. The problem of corruption is a great threat to the proper functioning of Poland. Good law means security and undisturbed development of its citizens, it is also a guarantee of security and a sense of social justice. Formulating good law is a very difficult task and requires conducting parallel activities on many levels of state functioning and the involvement of many structures and bodies. Corruption is a big problem. Most often, corruption occurs as a phenomenon, a problem etc. Corruption is above all a crime, it's breaking the law, it's cheating the state and citizens. Corruption is usually an intelligent crime that requires precise regulations. It should be remembered that even the best law alone is not enough to effectively prevent and combat corruption. In order for these activities to be effective, appropriate services should be well functioning to combat this form of crime, in particular: Central Anti-Corruption Bureau, Police, Internal Security Agency, National Tax Administration, Border Guard, Military Police, Prosecutor's Office and Courts.

\section{STRESZCZENIE}

Jednym z podstawowych elementów dających gwarancję dla skutecznego przeciwdziałania korupcji jest skuteczne prawo. Dobre prawo to bezpieczeństwo i niezakłócony rozwój jego obywateli, to również gwarancja bezpieczeństwa oraz poczucie sprawiedliwości społecznej. Formułowanie dobrego prawa to zadanie bardzo trudne i wymaga prowadzenia równoległych działań na wielu płaszczyznach funkcjonowania państwa oraz zaangażowania wielu struktur i organów.
\end{abstract}


Problem korupcji stanowi duże zagrożenie dla prawidłowego funkcjonowania Polski. Najczęściej korupcja występuje jako zjawisko, problem etc. Korupcja to przede wszystkim przestępstwo, to łamanie prawa, to oszukiwanie państwa i obywateli. Korupcja to najczęściej „przestępstwa inteligentne”, które wymagają precyzyjnych przepisów. Należy pamiętać, że samo prawo - nawet najlepsze - nie wystarczy, żeby skutecznie zapobiegać korupcji i ją zwalczać. Aby działania te były skuteczne, muszą dobrze funkcjonować odpowiednie służby powołane do zwalczania tej formy przestępczości, w szczególności: Centralne Biuro Antykorupcyjne, Policja, Agencja Bezpieczeństwa Wewnętrznego, Krajowa Administracja Skarbowa, Straż Graniczna, Żandarmeria Wojskowa, Prokuratura i Sądy.

KeYwoRDs: corruption, law, Central Anticorruption Bureau, Police, Internal Security Agency

SŁowA KLUCzowe: korupcja, prawo, Centralne Biuro Antykorupcyjne, Policja, Agencja Bezpieczeństwa Wewnętrznego

\section{WPROWADZENIE}

Korupcja występowała już w czasach biblijnych, należy zatem przyjąć hipotezę, że jest świetnie przygotowana do zachodzących zmian w funkcjonowaniu społeczeństw na przestrzeni wieków. Wiele wersów Starego Testamentu opisuje wręcz dosłownie praktyki korupcyjne urzędników, których motorem jest niepohamowana chciwość. Przykładem byli nieuczciwi handlarze [por. Księga Syracydesa 26, 29]; ludzie, którzy fałszowali wagi: „(...) będziemy (...) wagę podstępnie fałszować (...) kupować biednego za srebro, a ubogiego za parę sandałów i plewy pszeniczne będziemy sprzedawać (...)" [por. Księga Amosa, 8, 5-6]. Bardzo podobny przypadek opisany został w księdze proroka Micheasza, w której piętnowane są chciwość i nadużywanie stanowisk, prowadzące nawet do niewoli ubogich w ten sposób: „Biada tym, którzy planują nieprawość (...). Gdy pożądają pól, zagarniają je, gdy domów - to je zabierają; biorą w niewolę męża wraz z jego domem, człowieka z jego dziedzictwem" [por. Księga Micheasza 2, 1-2]. Inni urzędnicy - rządcy i sędziowie - wymuszają łapówki: o zyskach bezprawnych i podarkach pisze prorok Izajasz [por. Księga Izajasza, 33, 15-16]. Oczywiście nie zabrakło potępienia dla korupcji, wiele słów negujących i potępiających zjawisko korupcji znajdujemy na kartach Księgi Przysłów. Oto czytamy tu: „Król państwo 
umacnia sprawiedliwością, niszczy je ten, kto podatkami uciska” [por. Księga Przysłów 29, 4]. A w innym miejscu podobne słowa: „Burzy się dom przez zyski nieprawe, żyć będzie, kto darów nie znosi” [por. Księga Przysłów 15, 27]. I na koniec przypomnienie: „Kto oszukuje maluczkiego, znieważa jego Twórcę, lecz wychwala Go ten, kto okazuje łaskę biednemu” (w innym tłumaczeniu: „Kto ciemięży ubogiego, lży jego Stwórcę, czci Go ten, kto się nad biednym lituje" [por. Księga Przysłów 14, 31]).

Przedstawiony powyżej tylko fragment historii na temat początków korupcji wskazuje na potrzebę systemowego traktowania tej formy przestępczości. Skuteczne zwalczanie korupcji to aktualne i precyzyjne prawo oraz skuteczne służby.

\section{Konsty tucja Rzeczypospolitej Polskiej Z DNIA 2 KWIETNIA 1997 R.}

Konstytucja jest aktem o najwyższej mocy prawnej w systemie źródeł prawa w państwie. Reguluje w sposób oczywisty instytucje ustroju politycznego oraz społeczno-gospodarczego. Obowiązkiem każdego organu władzy publicznej jest przestrzeganie ustawy zasadniczej. Niedostosowanie się do zapisów Konstytucji może doprowadzić przedstawicieli władzy wykonawczej do poniesienia odpowiedzialności konstytucyjnej przed Trybunałem Stanu.

Zapisy poszczególnych artykułów umieszczonych w ustawie zasadniczej gwarantują prawa i wolności obywatelskie, precyzują stosunki pomiędzy władzą ustawodawczą, wykonawczą i sądowniczą. Wskazują sposób i formę powoływania instytucji państwowych, takich jak Senat, Sejm, Prezydent i Rada Ministrów. Konstytucja wpływa bezpośrednio na kształt systemu sądownictwa i organów kontroli państwowej, określa również organizację administracji rządowej, finanse publiczne oraz stany nadzwyczajne w kraju.

Zapewnienie politycznej neutralności jest realizowane za pośrednictwem art. 103 Konstytucji, który stanowi: „Mandatu posła nie można łączyć z funkcją Prezesa Narodowego Banku Polskiego, Prezesa Najwyższej Izby Kontroli, Rzecznika Praw Obywatelskich, Rzecznika Praw Dziecka i ich zastępców, członka Rady Polityki Pieniężnej, członka Krajowej Rady Radiofonii i Telewizji, ambasadora oraz z zatrudnieniem w Kancelarii Sejmu, Kancelarii Senatu, Kancelarii Prezydenta Rzeczypospolitej lub z zatrudnieniem w administracji 
rządowej. Zakaz ten nie dotyczy członków Rady Ministrów i sekretarzy stanu w administracji rządowej. Sędzia, prokurator, urzędnik służby cywilnej, żołnierz pozostający w czynnej służbie wojskowej, funkcjonariusz policji oraz funkcjonariusz służb ochrony państwa nie mogą sprawować mandatu poselskiego. Inne przypadki zakazu łączenia mandatu poselskiego $\mathrm{z}$ funkcjami publicznymi oraz zakazu jego sprawowania może określić ustawa”.

Powyższy artykuł przedstawia wykaz funkcji publicznych i zawodów niepołączalnych z mandatem posła. Ponieważ funkcje posła i senatora są z natury polityczne, wykonywanie niektórych zawodów i prac mogłoby przebiegać w nieprawidłowy sposób. Artykuł ten wskazuje listę osób, które z powodu pełnionego stanowiska nie mogą piastować mandatu parlamentarzysty. $\mathrm{Ob}-$ jęcie jednego $\mathrm{z}$ wymienionych stanowisk przez posła lub senatora automatycznie wygasza mandat. Określa jednocześnie osoby, które nie mogą sprawować mandatu posła bądź senatora.

Na podstawie ust. 3 art. 103 można wywnioskować, że katalog wymienionych stanowisk nie został zamknięty. Ustawodawca może zadecydować, czy katalog ulegnie rozszerzeniu.

Według art. 107 Konstytucji: „W zakresie określonym ustawą poseł nie może prowadzić działalności gospodarczej z osiąganiem korzyści z majątku Skarbu Państwa lub samorządu terytorialnego ani nabywać tego majątku. Za naruszenie zakazów, o których mowa w ust. 1, poseł, uchwałą Sejmu podjętą na wniosek Marszałka Sejmu, może być pociągnięty do odpowiedzialności przed Trybunałem Stanu, który orzeka w przedmiocie pozbawienia mandatu".

Artykuł ten można określić mianem „antykorupcyjny”. Ustawodawca zapewne chciał zminimalizować wzbogacanie się posłów i senatorów kosztem majątku publicznego, wobec czego wprowadził zakaz prowadzenia przez parlamentarzystów działalności gospodarczej, która miałaby związek z wymienionymi korzyściami. Naruszenie powyższego zakazu może spowodować pociągnięcie parlamentarzysty do odpowiedzialności przed Trybunałem Stanu, w konsekwencji czego może on zostać pozbawiony mandatu.

Zgodnie z zapisami artykułu 132 Konstytucji: „Prezydent Rzeczypospolitej nie może piastować żadnego innego urzędu ani pełnić żadnej funkcji publicznej, z wyjątkiem tych, które są związane ze sprawowanym urzędem". 
Zasada fragmentacji władzy zakłada wyselekcjonowanie trzech władz, równocześnie rozłączność wykonywanych przez nie funkcji, a także niepołączalność w jednym ręku urzędów należących do różnorodnych władz. Wykluczone staje się pełnienie przez Prezydenta RP jakichkolwiek innych urzędów, stanowisk i wykonywanie funkcji publicznych. Dostrzec należy cel autorów Konstytucji: chodzi o to, by Prezydent nie był uwikłany w bieżącą politykę. Taki stan rzeczy zapewnia głowie państwa bezstronność, co zapobiega m.in. zjawisku korupcji na najwyższym szczeblu władzy. Możliwe jest, aby Prezydent pełnił dodatkowo funkcje związane z urzędem lub te o znaczeniu honorowym. Przykładem może być przewodniczenie Kapitule Orderu Orła Białego bądź patronat nad przedsięwzięciem charytatywnym.

Zgodnie $\mathrm{z}$ art. 153 Ustawy zasadniczej: „W celu zapewnienia zawodowego, rzetelnego, bezstronnego i politycznie neutralnego wykonywania zadań państwa, w urzędach administracji rządowej działa korpus służby cywilnej. Prezes Rady Ministrów jest zwierzchnikiem korpusu służby cywilnej”.

Mając na uwadze stabilność i sprawne działanie państwa, powołany został na mocy tego przepisu Konstytucji korpus służby cywilnej. Otrzymał on rangę konstytucyjną i obejmuje apolityczną administrację rządową. Korpus stworzony został przez urzędników służby cywilnej, których położenie nie powinno się zmieniać pod wpływem ewolucji układu politycznego. Zwierzchnikiem korpusu jest Prezes Rady Ministrów, który z tego tytułu powołuje jego członków. Co zaś dotyczy zapobiegania zjawisku korupcji w państwie, urzędnik służby cywilnej nie może przynależeć do żadnej partii politycznej. Jest zatem osobą zupełnie apolityczną. Zakazane jest także łączenie urzędu z określonymi zajęciami.

Zgodnie z zapisami art. 178 Konstytucji: „Sędziowie w sprawowaniu swojego urzędu są niezawiśli i podlegają tylko Konstytucji oraz ustawom. Sędziom zapewnia się warunki pracy i wynagrodzenie odpowiadające godności urzędu oraz zakresowi ich obowiązków. Sędzia nie może należeć do partii politycznej, związku zawodowego ani prowadzić działalności publicznej nie dającej się pogodzić z zasadami niezależności sądów i niezawisłości sędziów”.

Niezawisłość sędziowska jest zasadą demokratycznego państwa prawa. Tylko niezawisły sąd może strzec wolności i prawa obywateli. Wymieniony artykuł gwarantuje, że sędzia podlega jedynie Konstytucji oraz ustawom. 
Dzięki temu sędzia działa zgodnie z prawem, swoim sumieniem oraz przekonaniem. Karygodne jest wywieranie nacisku na sędziego w kwestii decyzji, które podejmuje, co w dzisiejszych czasach pozwala zapobiec rozszerzeniu się zjawiska korupcji w państwie.

Zaprezentowane postanowienia konstytucyjne mają strzec naczelnej natury Konstytucji, jaką jest zasada uznająca Rzeczpospolitą Polską za dobro wspólne całego narodu.

\section{USTAWA Z DNIA 6 CZERWCA 1997 R. KODEKS KARNY}

Przestępstwa o charakterze korupcyjnym w polskim Kodeksie karnym zapisane są przede wszystkim w rozdziale XXIX pt.: „Przestępstwa przeciwko działalności instytucji państwowych oraz samorządu terytorialnego”. To zasadniczy akt prawny, na podstawie którego w Polsce zwalczana jest przestępczość korupcyjna.

Zgodnie z zapisami art. 228 kk: „Kto, w związku z pełnieniem funkcji publicznej, przyjmuje korzyść majątkową lub osobistą albo jej obietnicę, podlega karze pozbawienia wolności od 6 miesięcy do lat 8 . W wypadku mniejszej wagi, sprawca podlega grzywnie, karze ograniczenia wolności albo pozbawienia wolności do lat 2 . Kto, w związku z pełnieniem funkcji publicznej, przyjmuje korzyść majątkową lub osobistą albo jej obietnicę za zachowanie stanowiące naruszenie przepisów prawa, podlega karze pozbawienia wolności od roku do lat 10 . Karze określonej w $₫ 3$ podlega także ten, kto, w związku z pełnieniem funkcji publicznej, uzależnia wykonanie czynności służbowej od otrzymania korzyści majątkowej lub osobistej albo jej obietnicy lub takiej korzyści żąda. Kto, w związku z pełnieniem funkcji publicznej, przyjmuje korzyść majątkową znacznej wartości albo jej obietnicę, podlega karze pozbawienia wolności od lat 2 do 12 . Karom określonym w $₫ 1-5$ podlega odpowiednio także ten, kto, w związku z pełnieniem funkcji publicznej w państwie obcym lub w organizacji międzynarodowej, przyjmuje korzyść majątkową lub osobistą albo jej obietnicę lub takiej korzyści żąda, albo uzależnia wykonanie czynności służbowej od jej otrzymania”.

Aby móc prawidłowo zinterpretować wyżej przytoczony przepis, należy przede wszystkim wyjaśnić kilkakrotnie cytowany w tym podrozdziale zwrot „korzyść majątkowa”. 
„Korzyść majątkowa - każde dobro, które jest w stanie zaspokoić określoną potrzebę, a jego wartość da się wyrazić w pieniądzu. Może nią być nie tylko przyrost majątku, ale i wszystkie korzystne umowy, np. pożyczka udzielona na korzystnych warunkach, lub obniżka przy zakupie pewnych dóbr" (https://pl.wikipedia.org/wiki/Korzy\%C5\%9B\%C4\%87_maj\%C4\%85tkowa).

Zdaniem T. Bojarskiego „korzyść osobista” to świadczenia mające charakter niemajątkowy o dużym znaczeniu dla osoby, która je uzyskuje.

Typem podstawowym przestępstwa jest przyjmowanie korzyści majątkowej lub osobistej bądź jej obietnicy w związku z pełnieniem funkcji publicznej. Przedmiotem ochrony jest bezstronne i prawidłowe działanie osób zajmujących urzędy publiczne. Aby można było mówić o sprzedajności, osoba, która zajmuje państwowe stanowisko, musi ową korzyść przyjąć lub jej zażądać. Zgodnie z Kodeksem karnym większą odpowiedzialność poniesie sprawca, który przyjął łapówkę i naruszył przy tym przepisy prawa. Naruszeniem prawa bez wątpienia można nazwać także podjęcie działania, do którego nie było podstawy prawnej i faktycznej, jak i zaprzestanie wykonania praktyki służbowej, do której sprawca był zobowiązany. Porządkowym typem łapówkarstwa biernego jest uzależnienie czynności urzędniczej od otrzymanej korzyści majątkowej. W tej kwestii podejrzany wymownie daje do zrozumienia, że spełnienie przez niego żądań dotyczących czynności służbowej nadejdzie dopiero po otrzymaniu korzyści. Wysokość zagrożenia karnego zróżnicowano w zależności od wymiaru przestępstwa. Mając na myśli typ podstawowy przestępstwa $\mathrm{z}$ art. 228, sprawcę można pozbawić wolności od 6 miesięcy do 8 lat.

Art. 229 kk stanowi: „Kto udziela albo obiecuje udzielić korzyści majątkowej lub osobistej osobie pełniącej funkcję publiczną w związku z pełnieniem tej funkcji, podlega karze pozbawienia wolności od 6 miesięcy do lat 8 . W wypadku mniejszej wagi, sprawca podlega grzywnie, karze ograniczenia wolności albo pozbawienia wolności do lat 2. Jeżeli sprawca czynu określonego w $\$ 1$ działa, aby skłonić osobę pełniącą funkcję publiczną do naruszenia przepisów prawa lub udziela albo obiecuje udzielić takiej osobie korzyści majątkowej lub osobistej za naruszenie przepisów prawa, podlega karze pozbawienia wolności od roku do lat 10. Kto osobie pełniącej funkcję publiczną, w związku z pełnieniem tej funkcji, udziela albo obiecuje 
udzielić korzyści majątkowej znacznej wartości, podlega karze pozbawienia wolności od lat 2 do 12 . Karom określonym w $\$ 1-4$ podlega odpowiednio także ten, kto udziela albo obiecuje udzielić korzyści majątkowej lub osobistej osobie pełniącej funkcję publiczną w państwie obcym lub w organizacji międzynarodowej, w związku z pełnieniem tej funkcji. Nie podlega karze sprawca przestępstwa określonego w $\$ 1-5$, jeżeli korzyść majątkowa lub osobista albo ich obietnica zostały przyjęte przez osobę pełniącą funkcję publiczną, a sprawca zawiadomił o tym fakcie organ powołany do ścigania przestępstw i ujawnił wszystkie istotne okoliczności przestępstwa, zanim organ ten o nim się dowiedział".

Powyższy artykuł traktuje o przestępstwie łapownictwa czynnego, potocznie mówiąc: o przekupstwie. Proces ten polega na wręczaniu korzyści osobie pełniącej urząd państwowy. Artykuł znacząco odróżnia się od poprzedniego, jako że mamy do czynienia z odpowiedzialnością ponoszoną przez osobę wręczającą korzyść materialną lub osobistą. W tym przypadku udzieleniem korzyści można nazwać każdą formę bezpośredniego lub pośredniego jej dostarczenia osobie pełniącej posadę publiczną. Odbiorcą może być osoba, która pełni urząd publiczny, niemniej jednak ma ona moc wpłynięcia swoim działaniem na finalny efekt postępowania. Przestępstwo zawarte w art. 229 ma charakter powszechny, zatem sprawcą może być każdy człowiek zdolny do ponoszenia odpowiedzialności karnej. Podobnie jak w art. 228, sprawcę można pozbawić wolności od 6 miesięcy do 8 lat. Ustanawiając wyżej wymieniony przepis, ustawodawca miał na celu ułatwienie uzyskiwania przez organy ścigania informacji dotyczących wręczania łapówek. W związku z czym w zamian za zawiadomienie organów ścigania o udzieleniu korzyści majątkowej lub osobistej wprowadził dobrodziejstwo niepodlegania karze dla sprawcy czynu.

Zgodnie z art. 230 kk: „Kto, powołując się na wpływy w instytucji państwowej, samorządowej, organizacji międzynarodowej albo krajowej lub w zagranicznej jednostce organizacyjnej dysponującej środkami publicznymi albo wywołując przekonanie innej osoby lub utwierdzając ją w przekonaniu o istnieniu takich wpływów, podejmuje się pośrednictwa w załatwieniu sprawy w zamian za korzyść majątkową lub osobistą albo jej obietnicę, podlega karze pozbawienia wolności od 6 miesięcy do lat 8". 
W powyższym przepisie mamy do czynienia z przestępstwem płatnej protekcji. Dotyczy ona powoływania się na czyjeś wpływy w instytucjach lub urzędach, jak również podejmowania się pośrednictwa w załatwieniu sprawy w zamian za otrzymanie korzyści majątkowej lub osobistej. Przepis ten miał doprowadzić do prawidłowego i bezstronnego funkcjonowania instytucji państwowych oraz zapobiec skorumpowaniu urzędników. Do popełnienia przestępstwa można zaliczyć fakt, że sprawca powołał się na swoje znajomości i powiązania $z$ daną instytucją. Jak we wcześniejszych przypadkach, przestępstwo to należy zakwalifikować do powszechnych, w związku z czym sprawcą może być zarówno funkcjonariusz publiczny, jak i zwykły obywatel.

Kwestię dotyczącą osiągania korzyści majątkowych reguluje również art. 231 kk. Jego treść brzmi następująco: „Funkcjonariusz publiczny, który, przekraczając swoje uprawnienia lub nie dopełniając obowiązków, działa na szkodę interesu publicznego lub prywatnego, podlega karze pozbawienia wolności do lat 3. Jeżeli sprawca dopuszcza się czynu określonego w $\$ 1 \mathrm{w}$ celu osiągnięcia korzyści majątkowej lub osobistej, podlega karze pozbawienia wolności od roku do lat 10 . Jeżeli sprawca czynu określonego w $\$ 1$ działa nieumyślnie i wyrządza istotną szkodę, podlega grzywnie, karze ograniczenia wolności albo pozbawienia wolności do lat 2 . Przepisu $\$ 2$ nie stosuje się, jeżeli czyn wyczerpuje znamiona czynu zabronionego określonego w art. 228".

Artykuł ten określa przestępstwo, które polega na przekroczeniu uprawnień lub obowiązków przez funkcjonariusza publicznego. Surowsza odpowiedzialność sprawcy zależna jest od celu osiągnięcia korzyści majątkowej lub osobistej. Naruszenie prawa związane z przekroczeniem uprawnień ma miejsce wtedy, gdy sprawca podejmuje praktyki wykraczające poza jego kompetencje. Sprawca może jednocześnie nie dopełnić swoich obowiązków czy też wykonać je nienależycie. Sprawcą powyższego przestępstwa może być wyłącznie osoba będąca funkcjonariuszem publicznym, wobec czego przestępstwo ma charakter indywidualny właściwy.

Zagrożeniem dla sprawnie funkcjonującego państwa jest również przestępstwo korupcji wyborczej. Reguluje ją art. 250a kk. Zgodnie z jego treścią: „Kto, będąc uprawniony do głosowania, przyjmuje korzyść majątkową lub osobistą albo takiej korzyści żąda za głosowanie w określony sposób, podlega karze pozbawienia wolności od 3 miesięcy do lat 5. Tej samej karze podlega, kto udziela 
korzyści majątkowej lub osobistej osobie uprawnionej do głosowania, aby skłonić ją do głosowania w określony sposób lub za głosowanie w określony sposób”.

Przepisy umieszczone w wyżej wymienionym artykule miały zapewnić prawidłową realizację praw wyborczych. Przede wszystkim priorytetem staje się prawo obywateli do głosowania w sposób wolny i bezstronny. Istotą czynu zabronionego jest przyjmowanie przez osobę posiadającą uprawnienia do głosowania korzyści zarówno majątkowej, jak i osobistej w zamian za głosowanie w uzgodniony sposób, zgodny z oczekiwaniami osoby wręczającej korzyści. Przekupstwo staje się środkiem zmierzającym do wywarcia wpływu na decyzję o zmianie wyników głosowania. Przestępstwo to można zakwalifikować do przestępstw o charakterze formalnym. Bowiem zgodnie z kk sprzedajność wyborcza może być popełniona przez działanie i zaniechanie, zaś przekupstwo wyborcze tylko przez zaniechanie.

Należy zwrócić również uwagę na art. 296a „Kto, pełniąc funkcję kierowniczą w jednostce organizacyjnej wykonującej działalność gospodarczą lub pozostając z nią w stosunku pracy, umowy zlecenia lub umowy o dzieło, żąda lub przyjmuje korzyć majątkową lub osobistą albo jej obietnicę, w zamian za nadużycie udzielonych mu uprawnień lub niedopełnienie ciążącego na nim obowiązku mogące wyrządzić tej jednostce szkodę majątkową albo stanowiące czyn nieuczciwej konkurencji lub niedopuszczalną czynność preferencyjną na rzecz nabywcy lub odbiorcy towaru, usługi lub świadczenia, podlega karze pozbawienia wolności od 3 miesięcy do lat 5".

Ustawodawca miał na celu ochronić prawidłowość i rzetelność obrotu gospodarczego. Korupcję gospodarczą można scharakteryzować jako przyjęcie korzyści majątkowej lub osobistej przez osobę, która pełni funkcje kierownicze w podmiocie prowadzącym działalność gospodarczą w zamian za czyn nieuczciwej konkurencji bądź czynność preferencyjną na rzecz nabywcy lub odbiorcy towaru czy usług. Przykładem może być udzielenie kredytu niewypłacalnemu dłużnikowi, jak również ujawnienie tajemnicy handlowej przedsiębiorstwa. Odmiana sprzedajności gospodarczej określonej w powyższym artykule polega na umyślności w postaci zamiaru bezpośredniego. Niemożliwe jest popełnienie przestępstwa w zamiarze ewentualnym. Sprawca musi mieć pełną świadomość, za co otrzymał korzyść, jak również musi wykazać chęć jej przyjęcia. Za popełnienie powyższego czynu grozi kara pozbawienia wolności od 3 miesięcy do 5 lat. 
Ostatnim artykułem regulującym kwestię korupcji w Polsce jest art. 305 kk zawarty w rozdziale XXXVI pt. „Przestępstwa przeciwko obrotowi gospodarczemu”. Stanowi on bowiem: „Kto, w celu osiągnięcia korzyści majątkowej, udaremnia lub utrudnia przetarg publiczny albo wchodzi w porozumienie $z$ inną osobą działając na szkodę właściciela mienia albo osoby lub instytucji, na rzecz której przetarg jest dokonywany, podlega karze pozbawienia wolności do lat 3. Tej samej karze podlega, kto w związku z publicznym przetargiem rozpowszechnia informacje lub przemilcza istotne okoliczności mające znaczenie dla zawarcia umowy będącej przedmiotem przetargu albo wchodzi w porozumienie $\mathrm{z}$ inną osobą, działając na szkodę właściciela mienia albo osoby lub instytucji, na rzecz której przetarg jest dokonywany".

Zacytowany wyżej artykuł formułuje dwa występki, których celem jest utrudnianie prawidłowego przebiegu przetargu publicznego. Zdaniem T. Bojarskiego, aby popełnić owe przestępstwa, nie jest potrzebne osiągnięcie korzyści majątkowej, tylko podjęcie działań mogących zaszkodzić gospodarce rynkowej. Naruszenie prawa może mieć miejsce zarówno wskutek działania, jak i zaniechania. W tymże przestępstwie mamy do czynienia $z$ dwoma trybami ścigania. Podstawowym trybem jest publicznoskargowy, z urzędu, jeżeli pokrzywdzonym jest Skarb Państwa, a także na wniosek pokrzywdzonego, jeżeli występują inni pokrzywdzeni.

Przyjęte przez ustawodawcę uregulowania miały na celu efektywne zwalczanie korupcji poprzez zastosowanie sankcji karnej. Uregulowania te mają również pełnić funkcję profilaktyczną. Zostały wprowadzone, aby rozbić objawiającą się w zmowie milczenia solidarność pomiędzy przyjmującym korzyść a osobą wręczającą.

\section{USTAWA Z DNIA 21 SIERPNIA 1997 R. O OGRANICZENIU PROWADZENIA DZIALALNOŚCI GOSPODARCZEJ PRZEZ OSOBY PEENIĄCE FUNKCJE PUBLICZNE}

Ten akt prawny obejmuje uregulowania, które mają na celu zapobiegać wykorzystywaniu urzędów publicznych do realizowania osobistych interesów. Prawodawca, wprowadzając ograniczenia, miał na myśli wyeliminowanie konfliktu interesów w przypadku jednoczesnego pełnienia urzędu publicznego i czerpania pożytku materialnego w związku z zatrudnieniem w sektorze gospodarczym. 
Intencją ustawy było wykluczenie osób wykorzystujących urzędy publiczne do osiągania własnych korzyści. Miała jednocześnie minimalizować angażowanie się osób publicznych w sytuacje mogące podważyć ich autorytet, ale równocześnie uszczuplić zaufanie wyborców do organów państwa. Wprowadzając zakaz łączenia spornych funkcji z działalnością gospodarczą, prawodawca zmierzał do zlikwidowania jednego ze źródeł korupcji, jakim może być powstawanie niesprzyjających układów korupcjogennych.

Artykuł 2 ustawy wskazuje na osoby, które pełnią najważniejsze funkcje i stanowiska w państwie. Odnosi się m.in. do: Prezydenta, Marszałka Sejmu, Prezes Rady Ministrów, sędziów Trybunału Konstytucyjnego, pracowników Najwyższej Izby Kontroli, Prezesa Prokuratorii Generalnej Skarbu Państwa oraz zwykłego pracownika urzędu gminy. W literaturze ustawę antykorupcyjną nazwano aktem szczególnym „w stosunku do ustaw regulujących sytuację pracowniczą funkcjonariuszy publicznych". Wynika z tego, że zakazy wyżej wymienionej ustawy nie dotykają ogółu pracowników administracji publicznej, lecz wąską grupę urzędników.

Osoba pełniąca stanowiska publiczne zgodnie z treścią art. 4 nie może być m.in. członkiem zarządu, rad nadzorczych, komisji rewizyjnych spółek prawa handlowego, członkiem zarządu fundacji prowadzących działalność gospodarczą oraz nie może prowadzić działalności gospodarczej na własny rachunek. Zakaz ten określony został w sposób nadrzędny i umowa ta ma charakter jednoznaczny. Sankcje naruszające zakazy wprowadzone w art. 4 zaprezentowane są $\mathrm{w}$ dwóch aspektach. Pierwszy jest uzależniony od podmiotu, który dopuścił się złamania zakazu, drugi zaś zależy od momentu, w którym znieważył zakaz. $\mathrm{W}$ takim razie stosowne jest rozważenie, czy złamanie zakazu miało miejsce przed powołaniem, czy po powołaniu. Ustawa narzuca również osobom przywołanym w art. 1 złożenie oświadczenia o działalności gospodarczej, która prowadzona jest przez małżonka, oraz o zamiarze jej podjęcia lub zmianie charakteru.

Ustawa antykorupcyjna nie zawiera preambuły wyjaśniającej motywy jej uchwalenia, jednak poprzez analizę treści czytelnik może sam je ustalić. Jej celem jest przede wszystkim przeciwdziałać patologiom, poprzez które może dojść do poszerzenia zjawiska korupcji w Polsce. 


\section{USTAWA Z DNIA 25 CZERWCA 2010 R. O SPORCIE}

Ustawa ta powstała w celu określenia trybu postępowania, dzięki któremu zapewniona zostanie ochrona zasad sportowych. Obejmuje ona fundamentalne regulacje prawne, które zostały ograniczone w sposób możliwy do minimum.

Regulacja zjawiska przestępczości korupcyjnej w sporcie znajduje się w rozdziale X ustawy pt.: „Przepisy karne”. Jak twierdzi Komisja Europejska: „korupcja, pranie pieniędzy i inne formy przestępstw finansowych dotykają sport na poziomie lokalnym, krajowym i międzynarodowym”. Fundamentalnym artykułem regulującym problem korupcji w sporcie jest art. 46 wyżej wymienionej ustawy. Przedstawia on dwa typy zachowania korupcyjnego, jakim jest sprzedajność sportowa i przekupstwo sportowe. Pierwowzorem przepisu był art. 296b Kodeksu karnego wcielony w życie na podstawie nowelizacji z 2003 r. Ulokowano go w rozdziale XXXVI, gdzie zgrupowane są typy czynów zabronionych, skierowanych przeciwko obrotowi gospodarczemu. Liczne wątpliwości interpretacyjne czynu zabronionego doprowadziły do uchylenia art. 296b przez art. 64 powyższej ustawy. Analizując paragraf, można zauważyć, że przestępstwo ma charakter powszechny, gdyż artykuł stanowi „kto”. Zatem podmiotem przestępstwa może być osoba dowolna. Podmiot rozumiany jest jako osoba, która dopuściła się udzielenia korzyści majątkowej lub osobistej osobie mającej wpływ na wynik końcowy zawodów sportowych. Korzyść ma więc stanowić ekwiwalent nieuczciwego zachowania, jakie ma dokonać sprawca. Sam wynik nie został w żaden sposób określony. Zatem nie ma znaczenia, o jaki konkretny wynik chodzi.

Następny artykuł zapobiegający patologii, jaką jest korupcja w sporcie, stanowi art. 48 wyżej wymienionej ustawy. Obejmuje on dwa typy przestępstw: płatną protekcję oraz przekupstwo za płatną protekcję w sporcie. Zdaniem M. Badury płatną protekcję należy rozumieć jako powoływanie się na wpływy w polskim związku sportowym. Choć nie zawsze związek ten musi mieć postać rzeczywistą. Może być wyłącznie fikcyjnym wymysłem sprawcy. Podmiotem naruszenia prawa może być każdy, wobec czego przestępstwo będzie miało charakter powszechny jak w przypadku art. 46. W momencie przyjęcia korzyści majątkowej lub osobistej w zamian za nieuczciwe zachowanie mające wpływ na osiągnięcia sportowe, zgodnie z ustawą grozi kara pozbawienia wolności do 8 lub 10 lat. 


\section{USTAWA Z DNIA 9 CZERWCA 2006 R. O CENTRALNYM BIURZE ANTYKORUPCYJNYM}

Według ustawy, Centralne Biuro Antykorupcyjne jest służbą specjalną powołaną do spraw zwalczania korupcji w życiu publicznym i gospodarczym, obejmując w szczególności swoim zakresem instytucje państwowe i samorządowe. Centralne Biuro Antykorupcyjne także zwalcza działalność godzącą w interesy ekonomiczne państwa.

W literaturze krajowej i zagranicznej funkcjonuje trudna do ustalenia liczba definicji korupcji. Ustawa o CBA spowodowała pewnego rodzaju porządek definicyjny, wprowadzając ustawową definicję korupcji.

Korupcją jest czyn:

1) polegający na obiecywaniu, proponowaniu lub wręczaniu przez jakąkolwiek osobę, bezpośrednio lub pośrednio, jakichkolwiek nienależnych korzyści osobie pełniącej funkcję publiczną dla niej samej lub dla jakiejkolwiek innej osoby, w zamian za działanie lub zaniechanie działania w wykonywaniu jej funkcji;

2) polegający na żądaniu lub przyjmowaniu przez osobę pełniącą funkcję publiczną, bezpośrednio lub pośrednio, jakichkolwiek nienależnych korzyści, dla niej samej lub dla jakiejkolwiek innej osoby, lub przyjmowaniu propozycji lub obietnicy takich korzyści, w zamian za działanie lub zaniechanie działania w wykonywaniu jej funkcji;

3) popełniany w toku działalności gospodarczej, obejmującej realizację zobowiązań względem władzy (instytucji) publicznej, polegający na obiecywaniu, proponowaniu lub wręczaniu, bezpośrednio lub pośrednio, osobie kierującej jednostką niezaliczaną do sektora finansów publicznych lub pracującej w jakimkolwiek charakterze na rzecz takiej jednostki, jakichkolwiek nienależnych korzyści, dla niej samej lub na rzecz jakiejkolwiek innej osoby, w zamian za działanie lub zaniechanie działania, które narusza jej obowiązki i stanowi społecznie szkodliwe odwzajemnienie;

4) popełniany w toku działalności gospodarczej obejmującej realizację zobowiązań względem władzy (instytucji) publicznej, polegający na żądaniu lub przyjmowaniu bezpośrednio lub pośrednio przez osobę kierującą jednostką niezaliczaną do sektora finansów publicznych lub pracującą w jakimkolwiek charakterze na rzecz takiej jednostki, jakichkolwiek nienależ- 
nych korzyści lub przyjmowaniu propozycji lub obietnicy takich korzyści dla niej samej lub dla jakiejkolwiek innej osoby, w zamian za działanie lub zaniechanie działania, które narusza jej obowiązki i stanowi społecznie szkodliwe odwzajemnienie.

Ważne z punktu widzenia prawidłowego rozumienia i definiowania pojęć związanych z korupcją jest także ustalenie ustawowej definicji działalności godzącej w interesy ekonomiczne państwa.

Działalnością godzącą w interesy ekonomiczne państwa jest każde zachowanie mogące spowodować w mieniu:

1) jednostki sektora finansów publicznych w rozumieniu przepisów o finansach publicznych,

2) jednostki niezaliczanej do sektora finansów publicznych otrzymującej środki publiczne,

3) przedsiębiorcy $z$ udziałem Skarbu Państwa lub jednostki samorządu terytorialnego - znaczną szkodę w rozumieniu art. $115 \$ 7$ ustawy z dnia 6 czerwca 1997 r. - Kodeks karny (Dz.U. z 2016 r. poz. 1137, z późn. zm.).

Idąc dalej, należy zaprezentować zadania CBA. Zgodnie z ustawą o CBA, do zadań CBA, w zakresie właściwości określonej w art. 1 ust. 1, należy:

1) rozpoznawanie, zapobieganie i wykrywanie przestępstw przeciwko:

a) działalności instytucji państwowych oraz samorządu terytorialnego, określonych w art. 228-231 ustawy z dnia 6 czerwca 1997 r. - Kodeks karny, a także o którym mowa w art. 14 ustawy z dnia 21 sierpnia 1997 r. o ograniczeniu prowadzenia działalności gospodarczej przez osoby pełniące funkcje publiczne (Dz.U. z 2017 r. poz. 1393),

b) wymiarowi sprawiedliwości, określonych w art. 232, art. 233, art. 234, art. 235, art. $236 \$ 1$ i art. $239 \$ 1$, wyborom i referendum, określonych w art. 250a, porządkowi publicznemu, określonych w art. 258, wiarygodności dokumentów, określonych w art. 270-273 i art. 277a $\$ 1$, mieniu, określonych w art. 286, obrotowi gospodarczemu, określonych w art. 296-297, art. 299 i art. 305, obrotowi pieniędzmi i papierami wartościowymi, określonych $\mathrm{w}$ art. 310 ustawy z dnia 6 czerwca 1997 r. - Kodeks karny, a także o których mowa w art. 585-592 ustawy 
z dnia 15 września 2000 r. - Kodeks spółek handlowych (Dz.U. z 2017 r. poz. 157) oraz określonych $w$ art. 179-183 ustawy $z$ dnia 29 lipca 2005 r. o obrocie instrumentami finansowymi (Dz.U. z 2017 r. poz. 1768), jeżeli pozostają w związku z korupcją lub działalnością godzącą w interesy ekonomiczne państwa,

c) finansowaniu partii politycznych, określonych w art. 49d i 49f ustawy z dnia 27 czerwca 1997 r. o partiach politycznych (Dz.U. z 2017 r. poz. 876 i 1089), jeżeli pozostają w związku z korupcją,

d) obowiązkom podatkowym i rozliczeniom $z$ tytułu dotacji i subwencji, określonych w rozdziale 6 ustawy z dnia 10 września 1999 r. - Kodeks karny skarbowy (Dz.U. z 2016 r. poz. 2137, z późn. zm.), jeżeli pozostają w związku z korupcją lub działalnością godzącą w interesy ekonomiczne państwa,

e) zasadom rywalizacji sportowej, określonych w art. 46-48 ustawy z dnia 25 czerwca 2010 r. o sporcie (Dz.U. z 2017 r. poz. 1463 i 1600),

f) obrotowi lekami, środkami spożywczymi specjalnego przeznaczenia żywieniowego, wyrobami medycznymi określonymi w art. 54 ustawy z dnia 12 maja 2011 r. o refundacji leków, środków spożywczych specjalnego przeznaczenia żywieniowego oraz wyrobów medycznych (Dz.U. z 2016 r. poz. 1536 i 1579 oraz z 2017 r. poz. 1200 i 1458) - oraz ściganie ich sprawców;

1a) ujawnianie mienia zagrożonego przepadkiem w związku z przestępstwami, o których mowa w pkt 1 ;

2) ujawnianie i przeciwdziałanie przypadkom nieprzestrzegania przepisów ustawy z dnia 21 sierpnia 1997 r. o ograniczeniu prowadzenia działalności gospodarczej przez osoby pełniące funkcje publiczne;

3) dokumentowanie podstaw i inicjowanie realizacji przepisów ustawy z dnia 21 czerwca 1990 r. o zwrocie korzyści uzyskanych niesłusznie kosztem Skarbu Państwa lub innych państwowych osób prawnych (Dz.U. poz. 255, z późn. zm.);

4) ujawnianie przypadków nieprzestrzegania określonych przepisami prawa procedur podejmowania i realizacji decyzji w przedmiocie: prywatyzacji i komercjalizacji, wsparcia finansowego, udzielania zamówień publicznych, rozporządzania mieniem jednostek lub przedsiębiorców, o których 
mowa w art. 1 ust. 4 oraz przyznawania koncesji, zezwoleń, zwolnień podmiotowych i przedmiotowych, ulg, preferencji, kontyngentów, plafonów, poręczeń i gwarancji kredytowych;

5) kontrola prawidłowości i prawdziwości oświadczeń majątkowych lub oświadczeń o prowadzeniu działalności gospodarczej osób pełniących funkcje publiczne, o których mowa w art. $115 \$ 19$ ustawy z dnia 6 czerwca 1997 r. - Kodeks karny, składanych na podstawie odrębnych przepisów;

6) prowadzenie działalności analitycznej dotyczącej zjawisk występujących w obszarze właściwości CBA oraz przedstawianie w tym zakresie informacji Prezesowi Rady Ministrów, Prezydentowi Rzeczypospolitej Polskiej, Sejmowi oraz Senatowi;

7) podejmowanie innych działań określonych w odrębnych ustawach i umowach międzynarodowych.

\section{Prawnokarna Konwencja o Korupcji z dnia 27 STYCZNIA $1999 \mathrm{R}$.}

W Strasburgu 27 stycznia 1999 r. 40 państw członkowskich Rady Europy uchwaliło Prawnokarną Konwencję o Korupcji. Zgodnie z komentarzem M. Wypych z Helsińskiej Fundacji Praw Człowieka głównym motywem sporządzenia Konwencji była ochrona społeczeństwa przed korupcją. Instrumentem do zaburzenia patologii miało być utworzenie stosownych norm ustawowych oraz środków zaradczych.

W preambule Konwencji wskazano, że korupcja zagraża „praworządności, demokracji, prawom człowieka, narusza dobre sprawowanie władzy, uczciwość i sprawiedliwość społeczną, spowalnia rozwój gospodarczy i zagraża stabilności instytucji demokratycznych i moralnym podstawom społeczeństwa”.

Konwencja jest dla państw wyznacznikiem pewnego minimum, które musi zostać spełnione. Oznacza to, że państwa mogą zachować własne przepisy, pod warunkiem że będą one co najmniej tak restrykcyjne jak przepisy porozumienia. $\mathrm{W}$ akcie tym nie zdefiniowano pojęcia korupcji w obawie pominięcia jakiejś kwestii, w związku z czym dokument ten charakteryzują szczegółowo opisane poszczególne przypadki.

Kluczowe zapisy odnoszące się do przestępstw korupcyjnych zawarte zostały w art. 2 i 3 Konwencji. Pierwszy z nich obejmuje czynne przekup- 
stwo krajowego funkcjonariusza publicznego. Państwa ratyfikujące powyższą Konwencję zobowiązały się do przyjęcia środków ustawodawczych niezbędnych do zaakceptowania przez prawo wewnętrzne za przestępstwo umyślne obiecywanie lub wręczanie korzyści przez osobę funkcjonariuszowi publicznemu w zamian za działanie lub zaniechanie działania w wykonywaniu jego funkcji. Przekupstwo bierne krajowego funkcjonariusza publicznego uregulowano w art. 3 wyżej wymienionego dokumentu.

W Konwencji wymieniono również przestępstwa czynne i bierne dotyczące członków zgromadzeń przedstawicielskich, członków zagranicznych zgromadzeń przedstawicielskich, funkcjonariuszy organizacji międzynarodowych, zagranicznych funkcjonariuszy publicznych, członków międzynarodowych zgromadzeń parlamentarnych, sędziów i funkcjonariuszy sądów międzynarodowych.

W Prawnokarnej Konwencji o Korupcji podjęto także zagadnienia przekupstwa w sektorze prywatnym, obrotu wpływami, prania pieniędzy z przestępstw korupcyjnych i przestępstwa księgowych.

Analizując treść artykułów Konwencji, można wydać opinię, że jest to dokument szczegółowy, a zarazem bardzo ambitny. Ustawodawca miał na celu objąć wszystkie typy przestępczości korupcyjnej, co w znaczny sposób umożliwiło ściganie przestępstw pozakrajowych i konfiskowanie środków pochodzących z nielegalnych źródeł.

\section{CyWilnoprawna KonWEnCJa O KorupCJ Z DNIA 4 LISTOPADA $1999 \mathrm{R}$.}

Jednym z priorytetów Rady Europy była redukcja zjawiska korupcji, w związku z czym przyjęcie Prawnokarnej Konwencji o Korupcji nie zakończyło podjęcia działań w tej kwestii. Dnia 4 listopada 1999 r. została przyjęta Cywilnoprawna Konwencja o Korupcji, która miała stać się instrumentem służącym do walki z korupcją za pomocą prawa cywilnego.

Zgodnie z treścią zawartą w preambule Konwencji: „korupcja stanowi wielkie zagrożenie dla rządów prawa, demokracji oraz praw człowieka, dla uczciwości i sprawiedliwości społecznej, powstrzymuje rozwój ekonomiczny oraz zagraża prawidłowemu i uczciwemu funkcjonowaniu gospodarki rynkowej". 
Celem tworzenia przepisów zawartych w powyższym dokumencie było zapewnienie skutecznych środków prawnych umożliwiających obronę praw oraz interesów osobom, które poniosły krzywdę w związku z przestępstwem korupcyjnym.

Jednym z kroków w tym kierunku była próba stworzenia przez ustawodawcę definicji korupcji, której nie umieszczono w Prawnokarnej Konwencji o Korupcji. Jej treść zawarta została w art. 2: „Dla celów niniejszej Konwencji, »korupcja« oznacza żądanie, proponowanie, wręczanie lub przyjmowanie, bezpośrednio lub pośrednio, łapówki lub jakiejkolwiek innej nienależnej korzyści lub jej obietnicy, które wypacza prawidłowe wykonywanie jakiegokolwiek obowiązku lub zachowanie wymagane od osoby otrzymującej łapówkę, nienależną korzyść lub jej obietnicę".

Utworzenie dokumentu niewątpliwie ustaliło minimalny standard w walce z przestępczością korupcyjną.

\section{KONWENCJA NAROdów ZJEDNOCZONYCH PRZECIWKO KORUPCJI}

Konwencja z dnia 31 października 2003 r. ,jest podstawowym dokumentem międzynarodowym w dziedzinie zapobiegania i zwalczania korupcji”.

Zdaniem C. Nowak z Fundacji im. Stefana Batorego jednym z zamiarów ustawodawcy było, aby Konwencja wyróżniała się na tle innych dokumentów związanych z problemem zjawiska korupcji. W związku z tym w Konwencji znalazły się zapisy dotyczące przyczyn i skutków korupcji, które zazwyczaj są pomijane $\mathrm{w}$ innych dokumentach międzynarodowych. Zawarte są przepisy mówiące, co należy zrobić, zanim konieczne będzie sięgnięcie do środków prawa karnego.

Wyżej opisany dokument wymaga od państw podpisujących Konwencję uznania za naruszenie prawa czyny obejmujące działania korupcyjne, w tym nie tylko defraudację majątku publicznego i przekupstwo, lecz także "pranie” zysków z korupcji. Konwencja rekomenduje państwom wyzwanie w postaci utworzenia środków zapobiegających i zwalczających zjawisko korupcji. Spodziewa się jednocześnie od państw zaangażowania obywatelskiego oraz współdziałania w zwalczaniu patologii i nakazuje obowiązek budowania polityki antykorupcyjnej. Wyraźny nacisk położono na udział społeczeństwa obywatelskiego we wszelkich działaniach zapobiegających praktykom korupcyjnym. 
Wiele kontrowersji budzi art. 31 Konwencji, w którym ustawodawcy proponują, aby mienie pochodzące $\mathrm{z}$ korupcji zostało przekazane innym państwom, szczególnie tym rozwijającym się, co w znacznym stopniu doprowadzi do współpracy pomiędzy stronami. Mając na względzie zgodność przepisów polskiego prawa z dokumentem, 15 września 2006 r. został on ratyfikowany przez Polskę.

\section{Podsumowanie}

Odnosząc się do powyższego materiału, można przyjąć następujące tezy:

- Polski system prawny jest wystarczający do skutecznej realizacji zwalczania korupcji.

- Centralne Biuro Antykorupcyjne posiada wszelkie prawne instrumenty pozwalające na sprawną walkę z korupcją.

- Przepisy prawne wprowadzają odpowiednie definicje, które pozwalają służbom i wymiarowi sprawiedliwości na właściwą realizację swoich zadań.

Aby poprawnie ocenić skuteczność obowiązującego prawa w zakresie zwalczania przestępczości korupcyjnej, należałoby przeprowadzić badania wyroków nakładanych na osoby, którym udowodniono w sposób prawomocny popełnienie przestępstw korupcyjnych.

W ramach dalszych działań analitycznych należałoby zastanowić się nad celowością karania przestępców korupcyjnych bezwzględnymi wyrokami - czy nie skuteczniejszym rozwiązaniem byłoby traktowanie przestępstw korupcyjnych jako przestępstw skarbowych, a przynajmniej część z nich.

\section{Literatura}

Badura, M. (2011). Ustawa o sporcie. Komentarz, Warszawa: Wolters Kluwer Polska. ISBN 9788326415142.

Bojarski, T. (2009). Kodeks karny. Komentarz, Warszawa: LexisNexis Polska. ISBN 9788376201023.

Chodak, P. (red.) (2015). Leksykon Bezpieczeństwo. Wybrane pojęcia, Józefów: Wydawnictwo WSGE. ISBN 9788362753543.

Górecki, D. (2009). Polskie prawo konstytucyjne w zarysie, Warszawa: Wolters Kluwer Polska. ISBN 9788376019628. 
Kosiński, J. (2011). Korupcja i antykorupcja. Wybrane zagadnienia, Szczytno: Wyższa Szkoła Policji. ISBN 9788393295494.

Pikulski S. (2002). Podstawowe zagadnienia bezpieczeństwa publicznego. W: J. Fiebiga, M. Roga, A. Tyburska (red.), Bezpieczeństwo to wspólna sprawa. Ochrona bezpieczeństwa publicznego - rozwiąania systemowe w skali kraju i regionu, materiaty poseminaryjne, Szczytno: Wyższa Szkoła Policji.

Pokruszyński W. (2009). Współczesne bezpieczeństwo narodowe, Józefów: Wydawnictwo WSGE. ISBN 8392193687.

Rzetecka-Gil, A. (2009). Ustawa o ograniczeniu prowadzenia działalności gospodarczej przez osoby petniace funkcje publiczne. Komentarz, Warszawa: Wolters Kluwer Polska. ISBN 8376014501.

Sitek, B. (2013). Własność municypalna a mienie komunalne. Wpływ doktryny politycznej na koncepcję własności komunalnej w perspektywie historyczno-porównawczej, „Journal of Modern Science” 1/16, p. 103-118. ISSN 1734-2031.

Sitek, M. (2016). Prawa (potrzeby) człowieka w ponowoczesności, Warszawa: Wydawnictwo C.H. Beck. ISBN 9788325589226.

Sitek, M. (2016). Respecting the human rights - the rights of immigrants. Between needs an capabilities of the countries hosting the migrants. W: M. Sitek, S. Stadniczeńko (red.), The rights of migrants between the needs and capabilities of the state and the international community, Józefów: Wydawnictwo WSGE, p. 55-66. ISBN 9788362753734 .

Skrzydło, W. (2000). Konstytucja RP. Komentarz, Kraków: Zakamycze. ISBN $838855171 \mathrm{X}$.

Such-Pyrgiel, M. (2008). Zjawisko singli w nowoczesnym społeczeństwie [w:] U. Bejma (red.) Społeczeństwo Polskie w procesie zmian. Warszawa: Wyd. UKSW."

Such-Pyrgiel M. (2018), Społeczny wymiar życia singli. Studium socjologiczne. Wydawnictwo Wyższej Szkoły Gospodarki Euroregionalnej im. Alcide De Gasperi w Józefowie, Józefów 2018, ISBN 978-83-62753-98-7.

Winczorek, P. (2000). Komentarz do Konstytucji RP z dnia 2 kwietnia 1997 roku, Warszawa: Liber. ISBN 8372060487. 


\section{Akty prawne}

Cywilnoprawna Konwencja o Korupcji z dnia 4 listopada 1999 r. (Dz.U. 2004 nr 244 poz. 2443).

Konstytucja Rzeczypospolitej Polskiej z dnia 2 kwietnia 1997 r. uchwalona przez Zgromadzenie Narodowe w dniu 2 kwietnia 1997 r., przyjęta przez Naród w referendum konstytucyjnym w dniu 25 maja 1997 r., podpisana przez Prezydenta Rzeczypospolitej Polskiej w dniu 16 lipca 1997 r. (tekst ujednolicony Dz.U. z 1997 r. Nr 78, poz. 483, z 2001 r. Nr 28, poz. 319, z 2006 r. Nr 200, poz. 1471, z 2009 r., Nr 114, poz. 946).

Konwencja Narodów Zjednoczonych przeciwko Korupcji (Dz.U. 2007 nr 84 poz. 563).

Prawnokarna Konwencja o Korupcji z dnia 27 stycznia 1999 r. (Dz.U. 2005 nr 29 poz. 249).

Rozporządzenie Prezydenta Rzeczypospolitej z dnia 11 lipca 1932 r. Kodeks karny (Dz.U. Nr 60 poz. 571).

Ustawa z dnia 13 czerwca 2003 r. o zmianie ustawy Kodeks karny oraz niektórych innych ustaw (Dz.U. nr 111 poz. 1061).

Ustawa z dnia 21 sierpnia 1997 r. o ograniczeniu prowadzenia działalności gospodarczej przez osoby pełniące funkcje publiczne (tekst ujednolicony Dz.U. z 2017 r. poz. 1393).

Ustawa z dnia 25 czerwca 2010 r. o sporcie (tekst ujednolicony Dz.U. z 2017 r. poz. 1463, 1600).

Ustawa z dnia 6 czerwca 1997 - Kodeks karny (tekst ujednolicony Dz.U. z 2017 r. poz. 2204 , z 2018 r. poz. 20).

Ustawa z dnia 6 kwietnia 1990 r. o Policji (tekst jednolity Dz.U. z 2016 r. poz. 1782 $\mathrm{z}$ późn. $\mathrm{zm}$.).

Ustawa z dnia 9 czerwca 2006 r. o Centralnym Biurze Antykorupcyjnym (tekst ujednolicony Dz.U. z 2017 r. poz. 1993, 2405). 